Anton Poliszczuk*

\title{
Ukraine's foreign trade: measuring dichotomies between East and West
}

Keywords: free trade, geographical structure, commodity structure, export

\begin{abstract}
For past decades the two major consumers of Ukrainian products have been the CIS countries and the EU, both making up to 55\% of the foreign trade turnover. An enactment of the Deep and Comprehensive Free Trade Area in 2016 has significantly boosted the trade between Ukraine and the EU Member States and, from other hand, has indirectly contributed to the reduction of trade with key CIS partners. In result, basically, has occurred a reorientation of Ukrainian trade from Eastern partners to Western. The analysis of the foreign trade of Ukraine for the period 2010-2019 has proved the thesis that Ukraine has gained first of all quantitatively in trade integration with the EU and lost first of all qualitatively in diminished trade with the CIS.
\end{abstract}

\section{Introduction}

In constantly changing economic and political environment around Ukraine the trade relations of the country with its neighbors have as well their certain progression. The Deep and Comprehensive Free Trade Area

* ORCID ID: https://orcid.org/0000-0002-4386-3469, magister Burgundzkiego Uniwersytetu we Francji w dziedzinie „Prawo Europejskie” oraz magister Opolskiego Uniwersytetu w Polsce w dziedzinie „Stosunki Międzynarodowe”. E-mail: anton.zt.ref.aval@gmail.com 
(further DCFTA) was signed in June 2014, but it started to be active only since $1^{\text {st }}$ January 2016 with the first important effects of it tangible from 2018. A downfall in trade with the CIS countries started from 2014 and has stabilized by 2018. Despite trade restrictions introduced already in 2014, Russia lost the position of Ukraine's top trade partner only in 2019. Thus in 2019 we have Ukraine that has already received first benefits from trade integration with the EU and has stabilized a downfall in trade relations with the CIS. This situation gives us an opportunity to draw first conclusion on Ukraine's trade reorientation from Eastern to Western partners in result of political and economic developments around country in past decade. The thesis of this article is the statement that by 2019 Ukraine has gained predominantly quantitatively in trade integration with the EU and has lost predominantly qualitatively in diminished trade with the CIS. In the context of this article under the term quality I understand technologically high-intensive and thereby more high value-added products in the structure of exports. The quantity is being understood as a nominal value of the exports.

The novelty of this article relies on the fact that the year 2019 is the first year relevant for the comparison of the situations in Ukraine's foreign trade before and after the enactment of the DCFTA in 2016.

The goal of this article is to analyze the foreign trade activity of Ukraine in goods with its key partners, the EU and the CIS in order to retrace the main qualitative and quantitative changes in purpose to prove or disprove the thesis of this article.

Materials and methods. The methodological basis of this article are the statistical data, the studies and the reviews of the "Statistics Committee of Ukraine" and analytical reports of state expert agencies on modern economic relations of Ukraine in field of foreign trade with the EU and the CIS countries. To study the thesis of this article, I have used data at the two-digit International Harmonized Commodity Description and Coding System on the main Ukrainian export commodities according to the classification that uses Eurostat for the aggregation of the manufacturing industries according to technological intensity on high, medium and low technology-intensive products ${ }^{1}$. Using a systematic approach, quantitative and descriptive methods has been analyzed the structure and dynamics of foreign trade in goods.

1 EUROSTAT aggregations of manufacturing based on NACE Rev. 2: https://ec.europa. eu/eurostat/cache/metadata/Annexes/htec_esms_an3.pdf (21.08.2020). 
Analysis of latest scientific works: There are a big number of works of domestic scientists devoted to Ukraine's foreign activity, such as H.M. Bogatskaya, G.V. Golubova, A. Dunskaya, T.L. Krasnoded, S. Kulitsky and others ${ }^{2}$. The classics of the theories about international trade are A. Smith, D. Ricardo, V. Leontiev, W. Olin, E. Heckscher and other scientists. Their works became the basis for the discussion on problems in Ukraine's foreign trade activity with other countries, problems of geographical and commodity composition of Ukrainian imports and exports, finding solutions to these problems by modern Ukrainian scientists such as S. Kulitsky, L. Ligonenko, A. Mazaraki, E. Savelyev and others. Scientists worked on identifying current trends and factors of development of Ukraine's foreign trade, substantiating the possibilities of attracting foreign investment, studying the impact of Ukraine's foreign activity on the country's economic growth.

After the dissolution of the USSR in 1991, an independent Ukrainian state in 1990s and 2000s was practicing multi-vector political and economic foreign policy. In the framework of the Commonwealth of Independent States(CIS) first of all, but also participating in other economic integration projects such as Single Economic Space or The Eurasian Economic Union (EAEU) Ukraine kept the old trade relations with the former USSR republics and simultaneously declared its interest in integration with the EU. Free trade between CIS members existed since 1991 in form of bilateral and multilateral agreements, when in 2011 has been signed a uniform free trade agreement by all CIS member states, including Ukraine ${ }^{3}$.

The first step toward integration with the EU had been accomplished in 2008 with the announcement of "Stabilization and Association” agreement, which later in 2012 has been transformed into the EU-Ukraine Association agreement that in its first parts contained an establishment of a free trade area between the Country and the Union. In November 2013 the president of the Ukraine Viktor Yanukovich postponed signature of the Association agreement, the step which caused discontent in Ukrainian society, rebellions into the streets, dismissal of Yanukovich and ultimately the signature by new Ukrainian president Petro Poroshenko

2 A.A.Mazaraki, Foreign Trade of Ukraine: XXI Century: Monograph. Kyiv National Economic University: KNTEU, s. 99.

3 V.P. Dalyk, N.I. Duliaba, Ukraine's foreign trade: realities and prospects of development, Scientific journal of Uzhhorodsky national university. Serie: International economic relations and development, p. 11. 
of the Association Agreement on March 2014. At this period Russia promoted its own project "Eurasian Custom Union" as a counterweight for Ukraine's integration into the EU. Ukrainian society at the time was divided into two parts, with 37\% supporting Ukraine's accession to the Custom Union of Belarus, Kazakhstan and Russia and 39\% supporting the country's integration with the European Union ${ }^{4}$. Here needs to be notified one important difference between the two choices, under the Eurasian Customs Union Ukraine would have less economic freedom as custom union presuppose a loss of a part of economic sovereignty under the establishment of a single custom tax and single external custom boarder, in which case it is not anymore possible for a member state to choose independently its trade partners, whereas in case of the EU Association Agreement Ukraine could have joined the Deep and Comprehensive Free Trade Area with European countries without losing free trade relations with CIS countries and other trade partners in the world. Thus, the Association with the EU complied much better with Ukraine's multi-vector foreign policy carried out since its independence ${ }^{5}$.

Ukraine since centuries has established strong economic ties with eastern CIS partners as they took part together in the USSR, the CIS market has always been an essential part in Ukraine's foreign trade activity making up to $40 \%$ of Ukrainian total trade turnover in goods. In November 2013 Ukraine had a unique historical chance to enlarge its free trade area with the European countries by signing the Association Agreement with the EU, while preserving its free trade relations with the CIS partners and establishing new connections with the rest of the world. An important difference between CIS and EU markets is higher competitiveness of the second one that in long run could have helped Ukrainian exporters to modernize their production thereby increasing the quality of their industries and the volumes of exports. However, well before the signature of the Association Agreement with the EU, the Russia Federation has announced its protest to it saying that DCFTA would humper trade activity between the countries and endanger Russian economy by the reexporting of originally EU goods from Ukraine to Russia 6 .

4 R. Menon, E.B. Rumer, Conflict in Ukraine: The Unwinding of the Post-Cold War Order (Boston Review Originals) Hardcover - February 6, 2015, p. 93.

5 S. Luginiets, Transformation of Ukrainian foreign trade flows in the context of Ukraine-EU association, "Journal of the European Economy» 2017, 16 (3), p. 234.

6 A.A. Mazaraki, Foreign Trade of Ukraine..., p. 196. 
Ukrainian "Euromaidan" revolution in 2014 catalyzed several important changes that affected the country's foreign trade activity. First, the EU and Ukraine have signed the DCFTA that entered into force from 1st January 2016. Secondly, Russia started to impose trade restrictions on Ukrainian imports that led to a full-fledged trade war between the countries which finally ended up with the suspension of the Free Trade Agreement by Russia as from 2nd January $2016^{7}$. The third change is a deep economic recession of 2014-2015, which was caused partially by political instability, the conflict on the east of the country and the annexation of the Crimean Peninsula. As a result, Ukraine's GDP and consequently foreign trade have diminished almost two times (see Figure 1).

Figure 1. Overall Ukrainian exports and imports of goods in comparison to GDP in 2010-2019

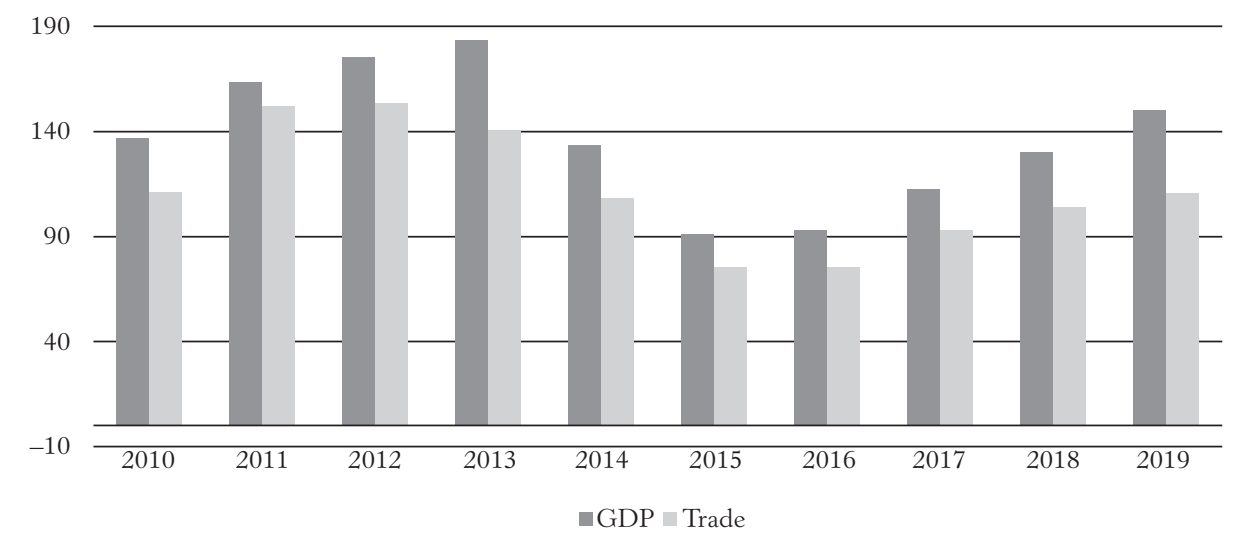

Source: own calculations based on data from Ukrainian Statistical State Agency: http://www. ukrstat.gov.ua/

\section{General macroeconomic indicators}

Before 2014 Ukrainian trade showed an increasing tendency with both, the EU and the CIS. After 2014, in accordance with the basic economic theories, the less country produce, the less country is capable to buy or to sell ${ }^{8}$, the fall of Ukrainian trade coincides with the fall of Ukrainian GDP

7 R. Menon, E.B. Rumer, Conflict in Ukraine..., p. 94.

8 T. Didier, M. Pinat, The nature of trade and growth linkages (Policy Research working paper No. WPS 8161), Washington, D.C. 2017. 
for the period 2014-2015 economic crisis and vise versa, the recovery of Ukrainian GDP coincides with the revitalization of foreign trade starting from 2016 (Figure 1). After the economic crisis ended, starting from 2016 and onward, Ukrainian trade boosted by gradually recovering economy (112.3, 130.1 and 150.4 billion dollars of GDP for the years 2017, 2018 and 2019 respectively) starts to rise and, importantly, in relation to trade with the EU by the year 2019 reaches its historic maximum value of 45 billion dollars. In the period between 2014 and 2019 both unions showed diametrically opposite trade activities in relation to Ukraine, trade with CIS countries has fallen almost three times from 50 billion in 2013 to 18 billion in 2019. From Figure 2 is evident one tectonic shift in Ukrainian trade relations, namely within past decade, for the first time in history, the EU has overpassed the CIS countries in overall trade turnover in goods with Ukraine. Here needs to be noted that this shift happened at the expanse of diminished trade activity with the CIS rather than thanks to increased trade with the EU (see Figure 2).

Figure 2. Trade in goods with CIS and EU in 2010-2019

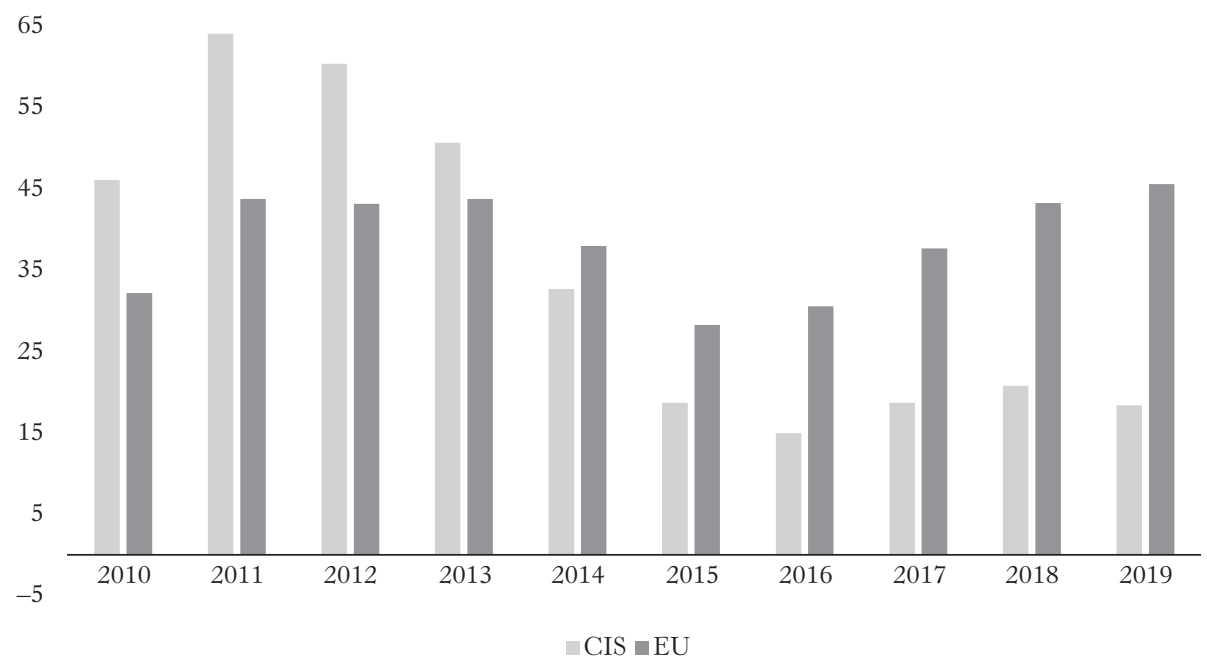

Source: own calculations based on data from Ukrainian Statistical State Agency: http://www. ukrstat.gov.ua/

A big part of decreased Ukrainian foreign trade falls to CIS countries and a substantial part of it belongs to the Russian market (Figure 3). Before 2013 Russia traded with Ukraine for up to 45 billion dollars per year, the share of Russia in overall trade turnover between Ukraine and CIS countries constituted up to 90\%. Apart of Russia, two other big- 
gest trade partners within CIS countries were Belarus (6.1 billion) and Kazakhstan (3.5 billion), trade with them in the 2014-2015 years recession period fall as well, but at incomparably less percentage than with Russia. After the crisis, trade with other CIS countries accept Kazakhstan and Russia has recovered averagely till the before crisis levels.

Concluding previous paragraphs is possible to retrace first East-West dichotomy, namely the trade activities with CIS and EU showed diametrically different progressions. The negative progression in trade with CIS countries happened predominantly at the expanse of diminished trade activity with Russian Federation.

Figure 3. Ukraine's trade in goods with CIS countries

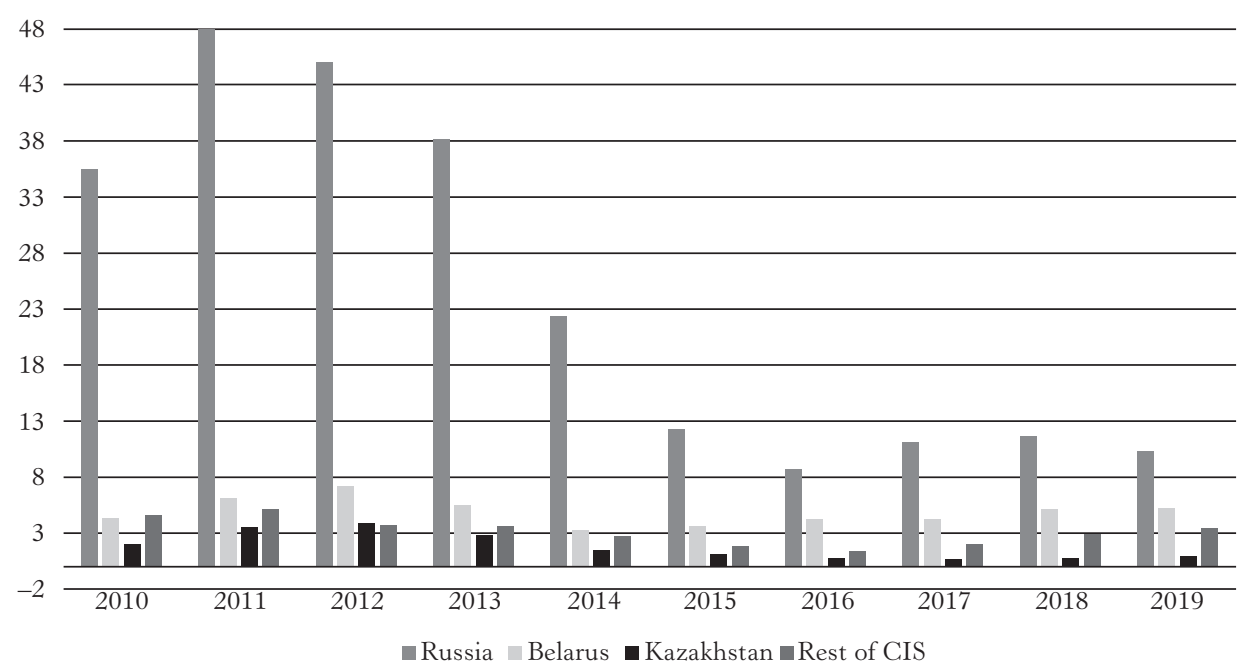

Source: own calculations based on data from Ukrainian Statistical State Agency: http://www. ukrstat.gov.ua/

\section{Geographical and commodity structure of Ukrainian exports}

Ukraine has a highly open economy with the foreign trade-to-GDP ratio making 95\% in 2019 (World's average ratio is 59\%) with the exports of goods thus being very important for the country's economic growth. In 2019 according to World Bank the exports of goods constituted 40.95\% of Ukraine's GDP9.

9 World Bank Statistics, Country profile: https://wits.worldbank.org/CountryProfile/en/ UKR (01.09.2020) 
Researches show strong evidence of the correlation between the quality of exports of goods and the general economic performance highlighting the positive impact of technology content products and the level of processing on GDP growth ${ }^{10}$. Countries with higher quality of exports are in a better position to reap benefits from trade integration and economic policies helping to shape sustainable economy. On the other hand, countries with low technology related products and low percentage of processed products in their exports find it difficult to enhance their economic performance level. In this paragraph, I will consider Ukrainian export from the point of technology content in it and the level of processing.

Figure 4. Commodity structure of Ukrainian exports in 2010-2019

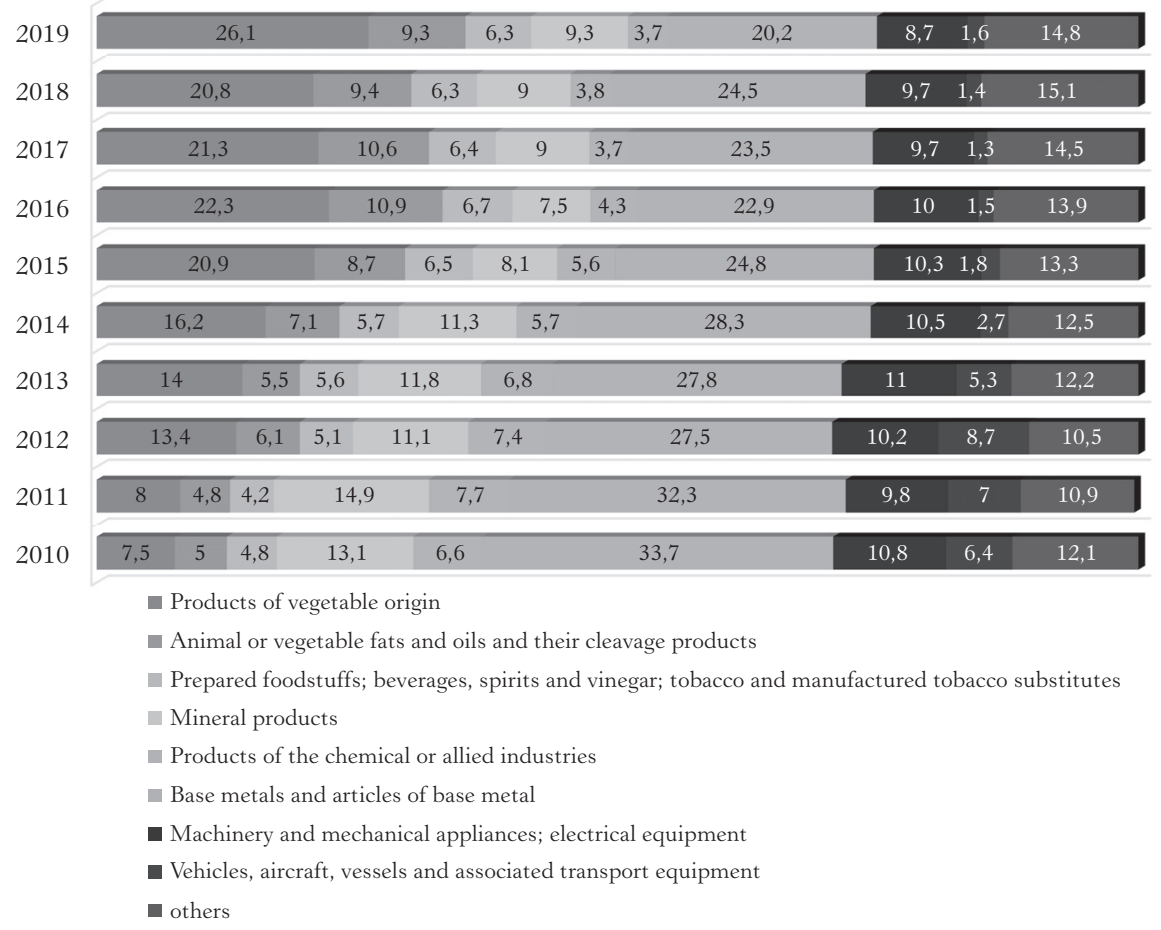

Source: own calculations based on data from Ukrainian Statistical State Agency: http://www. ukrstat.gov.ua/

Figure 4 shows commodity structure of total Ukrainian exports for years 2010-2019, from which we can observe a gradual shift toward

10 T. Didier, M. Pinat, The nature of trade and growth linkages..., p. 188. 
technologically less intensive industries. By 2019 agricultural and food industries have occupied $41.7 \%$ of all exports (in 2010 it was 17.3\%), whereas technologically more sophisticated commodity groups like vehicles, aircrafts, vessels and associated transport equipment, electronic and mechanic machinery, metallurgy and products of chemical industry have decreased. It needs to be noted that the only industry that clearly started to change its share after 2014 is the vehicles, aircrafts, vessels and associated transport equipment, all other industries started to have this tendency well before 2014, thus changes in these industries can't be attributed to DCFTA or to diminished trade with Russia.

As we have already revealed a big share of Russian market in Ukrainian exports, let's consider now more in detail how diminished trade between the countries has affected quantitatively and qualitatively Ukrainian exports to the Russian Federation. During only years 2014-2016, the trade turnover between Ukraine and the Russian Federation decreased by 4.4 times. Before 2014 Russia was an important partner-country for Ukrainian exporters placed on the first position among all the countries with its share of 24\% of all Ukrainian exports in 2013. In particular, trade disruptions with Russia have affected Ukraine's machine-building sector, which accounted for 3.5\% of Ukraine's GDP and 5.5\% of employment in $2012^{11}$.

Table 1 represents detailed data at the two-digit International Harmonized Commodity Description and Coding System on the main Ukrainian export commodities covering more than $90 \%$ of all exports for the years 2013 and 2019. Given years have been chosen for comparison as the year 2013 is the last year that wasn't affected neither by the economic crisis of 2014-2015, nor by the DCFTA or the trade restrictions with Russia. The year 2019 is the first year in which the downfall in trade with Russia has stabilized and Ukraine had tangible effects of the DCFTA. Table 1 represents relative importance of the EU, Russian and the rest of the world markets displaying their shares for each export commodity in percentage, in the rightmost column displayed ratio change of the nominal value of exports between 2013 and 2019 and the up/down arrows in the column "Exports in 2019" indicate an increase or decrease of the exports in a given commodity group for a given country/region (Russia, EU and the rest of the world) in the period between 2013 and 2019 years.

11 A.A. Mazaraki, Foreign Trade of Ukraine..., p. 174. 
Mechanical engineering is one of the most knowledge-intensive industries. From Table 1 we can see that, before 2013 Russian marked constituted up to $57 \%$ of all exports for commodity groups: "Nuclear Reactors, Boilers, Machinery and Mechanical Appliances", "Vehicles other than Railway or Tramway"; "Optical, Photographic, Cinematographic, Measuring, Precision, Medical or Surgical Instruments and Apparatus" and up to $72 \%$ for commodity groups: "Railway or Tramway Locomotives, Rolling-Stock and parts thereof"; "Articles of Paper Pulp, of Paper or of Paperboard". After 2014 exports of these products to Russia diminished averagely two to ten times and exports of "Aircraft, Spacecraft, and parts thereof" dropped to zero. Importance of Russian market before 2013 for technology-intensive industries is hard to overestimate.

Among the most prominent examples of Ukrainian companies that suffered from trade restrictions with Russia are "Antonov Design Bureau" famous by having constructed the world's biggest cargo plane Mriya, "Yuzhmash" specialized in space industry, "Motor Sich" - one of the largest engine manufacturers for airplanes and helicopters worldwide, "Marine Engineering Bureau" - an engineering Company in Odessa focused on development of products in the field of shipping and shipbuilding, "Dniprospetsstal" - steel plant in Zaporozhe producing special stainless steel, and others. For all these companies Russian market constituted a major part of their exports ${ }^{12}$. Interrupted Russian-Ukrainian cooperation in space and defense sectors harmed not only the affected production facilities in Ukraine (e.g. Yuzhmash in Dnipropetrovsk, Khatron-Arkos in Kharkiv producing space launchers and electronics), but also Russia and other CIS countries which used Ukraine-supplied rockets and electronic components in their defense industries ${ }^{13}$.

12 Ibidem, p. 179.

13 R. Menon, E.B. Rumer, Conflict in Ukraine..., p. 137. 


\begin{tabular}{|c|c|c|c|c|c|c|c|c|c|c|c|}
\hline \multicolumn{2}{|c|}{ 胥 } & $\stackrel{2}{1}$ & $\begin{array}{l}\stackrel{+}{0} \\
\dot{i}\end{array}$ & $\begin{array}{l}\stackrel{0}{0} \\
0\end{array}$ & กี & $\stackrel{?}{-}$ & m? & - & గొ & $\begin{array}{l}12 \\
0 \\
0\end{array}$ & $\stackrel{\text { f }}{\circ}$ \\
\hline \multirow{3}{*}{ 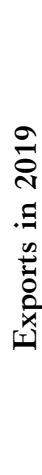 } & 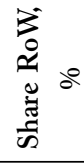 & $\begin{array}{l}\overrightarrow{\mathrm{N}} \\
\text { in }\end{array}$ & $\overleftarrow{\sigma}$ & $\begin{array}{l}\overleftarrow{\leftrightarrows} \\
\stackrel{+}{ \pm}\end{array}$ & $\overleftarrow{n}$ & ড্ & $\overleftarrow{8}$ & $\begin{array}{l}\overleftarrow{1} \\
8 \\
8\end{array}$ & $\begin{array}{l}\vec{t} \\
\stackrel{0}{n}\end{array}$ & $\begin{array}{l}\overrightarrow{+} \\
\vec{\theta}\end{array}$ & $\begin{array}{l}\overleftarrow{1 n} \\
\\
i n\end{array}$ \\
\hline & 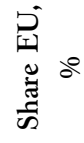 & 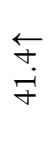 & 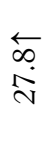 & 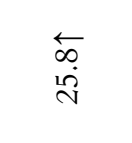 & 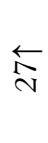 & $\begin{array}{l}\overleftarrow{-} \\
8\end{array}$ & $\overleftarrow{\sim}$ & $\overleftarrow{s}$ & 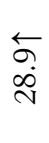 & $\begin{array}{l}\overleftarrow{广} \\
\stackrel{\leftrightarrow}{n}\end{array}$ & $\begin{array}{l}\vec{t} \\
\dot{t}\end{array}$ \\
\hline & 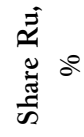 & $\vec{n}$ & $\vec{m}$ & $\overrightarrow{\overrightarrow{0}}$ & $\overrightarrow{0}$ & $\begin{array}{l}\overrightarrow{0} \\
\ddot{0}\end{array}$ & $\overrightarrow{0}$ & $\stackrel{\vec{n}}{\longrightarrow}$ & $\begin{array}{l}\stackrel{ }{ \pm} \\
\stackrel{\square}{ }\end{array}$ & $\vec{\overbrace{}}$ & $\overrightarrow{\overrightarrow{0}}$ \\
\hline \multirow{3}{*}{ 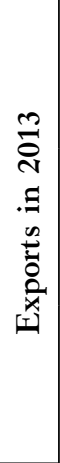 } & $\begin{array}{l}3 \\
0 \\
\frac{\pi}{0} \\
\frac{\pi}{5}\end{array}$ & $\stackrel{r}{r}$ & $\begin{array}{l}\infty \\
\dot{n} \\
\stackrel{n}{n}\end{array}$ & $\begin{array}{l}\hat{\infty} \\
\infty \\
m\end{array}$ & $\hat{N}$ & $\stackrel{r}{\dot{m}}$ & $+\infty$ & $\begin{array}{l}+ \\
\vec{\sigma}\end{array}$ & تॄ. & $\begin{array}{l}\dot{t} \\
\dot{\bullet}\end{array}$ & $\stackrel{\sim}{0}$ \\
\hline & 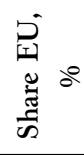 & $\stackrel{\text { In }}{\stackrel{\nu}{0}}$ & $\stackrel{n}{0}$ & $\overrightarrow{6}$ & $\hat{v}$ & 6 & $\stackrel{+}{ \pm}$ & $\stackrel{n}{\beth}$ & $\stackrel{n}{n}$ & $\stackrel{t}{0}$ & $\begin{array}{l}\infty \\
\stackrel{m}{ }\end{array}$ \\
\hline & 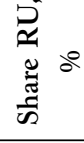 & $\begin{array}{l}\infty \\
\stackrel{\infty}{\sim}\end{array}$ & $\stackrel{a}{i n}$ & $\begin{array}{l}\text { Na } \\
\text { in } \\
\text { กิ) }\end{array}$ & $\stackrel{?}{0}$ & $\stackrel{+}{+}$ & $\stackrel{0}{-}$ & $\stackrel{t}{\dot{v}}$ & $\stackrel{n}{8}$ & $\frac{N}{n}$ & $\begin{array}{l}\stackrel{n}{+} \\
\stackrel{9}{+}\end{array}$ \\
\hline & 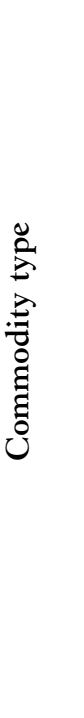 & 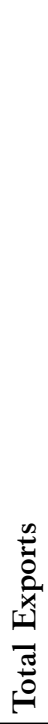 & 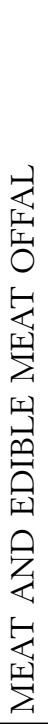 & 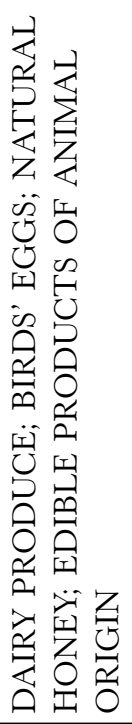 & 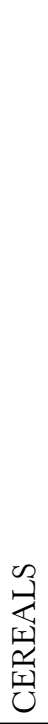 & 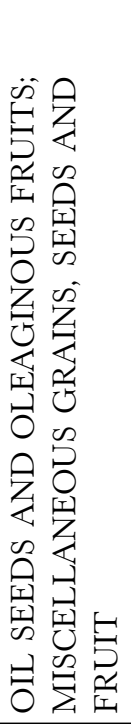 & 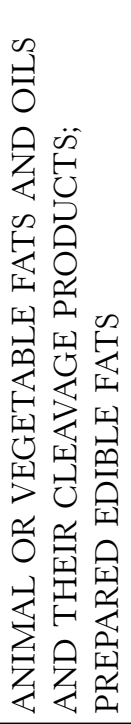 & 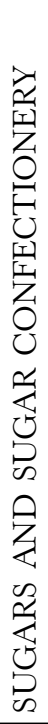 & 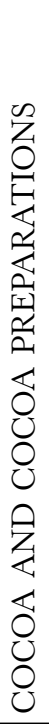 & 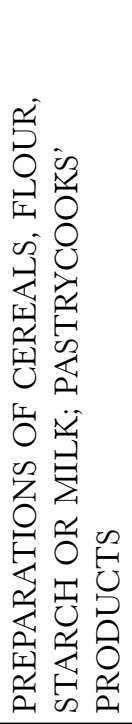 & 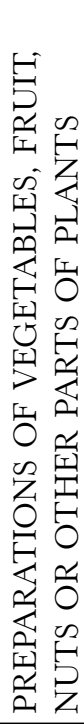 \\
\hline & & & 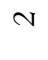 & + & $\stackrel{-}{-}$ & $\underset{\nearrow}{\nearrow}$ & $\stackrel{10}{n}$ & 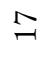 & $\stackrel{\infty}{\sim}$ & $\stackrel{2}{\rightarrow}$ & ㄱ \\
\hline
\end{tabular}


Ukraine's foreign trade: measuring dichotomies between East and West

\begin{tabular}{|c|c|c|c|c|c|c|c|c|c|c|c|c|}
\hline \multicolumn{2}{|c|}{ 芯 } & $\begin{array}{l}0 \\
\stackrel{2}{0} \\
0\end{array}$ & $\stackrel{n}{?}$ & & $\stackrel{\text { qे }}{\rightarrow}$ & 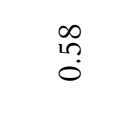 & مू & $\stackrel{m}{0}$ & 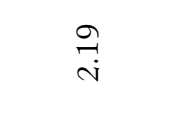 & $\stackrel{0}{0}$ & $\neg$ & $\stackrel{\circ}{\circ}$ \\
\hline \multirow{3}{*}{ 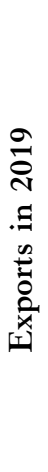 } & 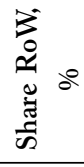 & $\begin{array}{l}\vec{\sim} \\
\stackrel{\vec{n}}{n}\end{array}$ & $\begin{array}{l}\overleftarrow{大} \\
\underset{\infty}{(}\end{array}$ & $\overleftarrow{6}$ & $\begin{array}{l}\overleftarrow{\infty} \\
\infty \\
\infty\end{array}$ & $\begin{array}{l}\vec{m} \\
\stackrel{i}{v}\end{array}$ & $\overrightarrow{\vec{n}}$ & $\begin{array}{l}\vec{\sigma} \\
\dot{ \pm}\end{array}$ & $\overrightarrow{\mathfrak{o}}$ & $\begin{array}{l}\rightrightarrows \\
\rightrightarrows\end{array}$ & $\begin{array}{l}\overleftarrow{\sigma} \\
\dot{\infty}\end{array}$ & $\vec{\imath}$ \\
\hline & 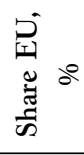 & $\begin{array}{l}\overleftarrow{广} \\
\text { ळे }\end{array}$ & $\stackrel{\overleftarrow{T}}{\overleftarrow{I}}$ & $\overleftarrow{n}$ & $\overleftarrow{\overleftarrow{\Upsilon}}$ & 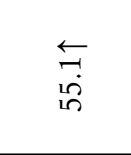 & $\overleftarrow{g}$ & $\vec{\infty}$ & 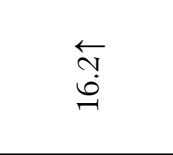 & 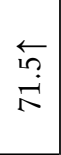 & $\overleftarrow{n}$ & $\underset{\mathrm{v}}{\vec{t}}$ \\
\hline & 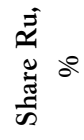 & $\overrightarrow{+}$ & $\overrightarrow{0}$ & $\overrightarrow{0}$ & $\overrightarrow{0}$ & $\begin{array}{l}\vec{b} \\
\dot{i} \\
\vec{v}\end{array}$ & $\overrightarrow{0}$ & $\overrightarrow{\vec{H}}$ & \begin{tabular}{l}
$\overleftarrow{6}$ \\
\multirow{1}{*}{}
\end{tabular} & 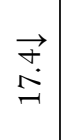 & $\begin{array}{l}\vec{\infty} \\
i \dot{0}\end{array}$ & $\overrightarrow{0}$ \\
\hline \multirow{3}{*}{ 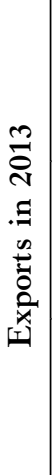 } & 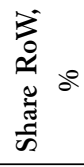 & $\stackrel{i}{\dot{0}}$ & in & $\begin{array}{l}9 \\
\dot{+}\end{array}$ & $\begin{array}{l}\hat{\infty} \\
\stackrel{\infty}{a}\end{array}$ & $\begin{array}{l}n \\
10 \\
\end{array}$ & $\hat{n}$ & $\begin{array}{l}\infty \\
\text { in } \\
\text { in }\end{array}$ & $\begin{array}{l}n \\
\text { n̊ }\end{array}$ & $\begin{array}{l}\stackrel{\Upsilon}{~} \\
\stackrel{\leftrightarrow}{S}\end{array}$ & $\stackrel{n}{\stackrel{+}{+}}$ & $\begin{array}{l}0 \\
i \infty \\
\infty\end{array}$ \\
\hline & 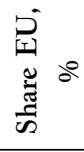 & $\underset{\infty}{+}$ & ִָ & $\begin{array}{l}\infty \\
\text { ஸ் } \\
\text { กิ }\end{array}$ & $\ddot{0}$ & $\stackrel{\infty}{=}$ & $\begin{array}{l}q \\
\dot{f}\end{array}$ & $\begin{array}{l}0 \\
\dot{0} \\
m\end{array}$ & 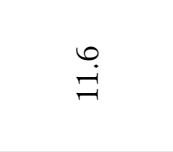 & $\infty$ & $\stackrel{7}{10}$ & $\stackrel{\oplus}{\ddot{r}}$ \\
\hline & 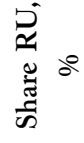 & F & $\overrightarrow{6}$ & mi & 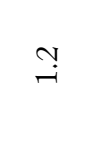 & ?ִ & $\stackrel{+}{-}$ & $\stackrel{0}{1}$ & 공 & $\begin{array}{l}\infty \\
\dot{0} \\
m\end{array}$ & $\stackrel{+}{\dot{0}}$ & $\stackrel{0}{0}$ \\
\hline & 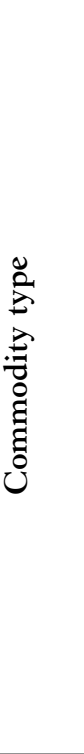 & 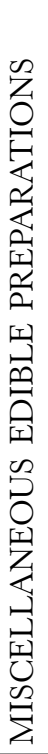 & 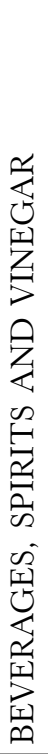 & 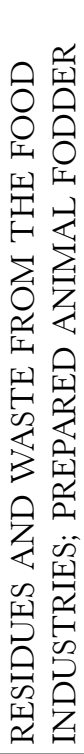 & 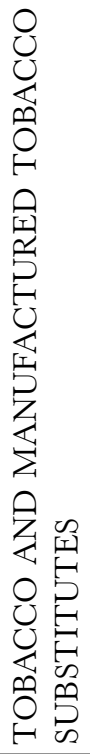 & 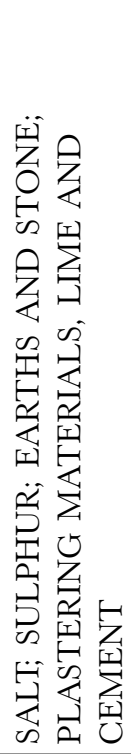 & 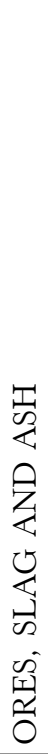 & 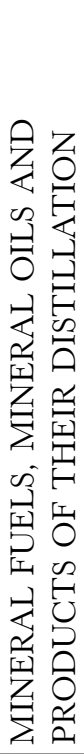 & 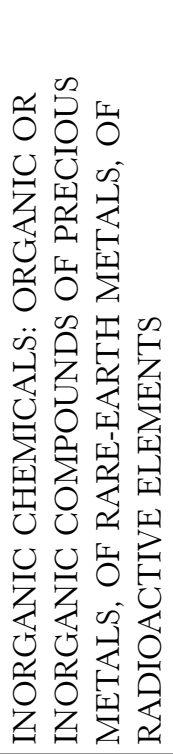 & 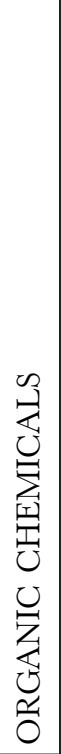 & 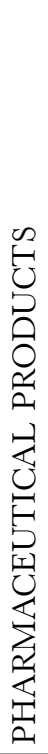 & 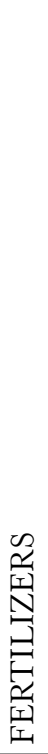 \\
\hline & & $\vec{\sim}$ & ป & $\approx$ & $\stackrel{+}{\sim}$ & 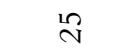 & $\underset{v}{\sim}$ & $\hat{\sim}$ & $\stackrel{\infty}{\sim}$ & $\stackrel{\mathrm{v}}{ }$ & i & $\vec{m}$ \\
\hline
\end{tabular}




\begin{tabular}{|c|c|c|c|c|c|c|c|c|c|c|c|c|}
\hline \multicolumn{2}{|c|}{ 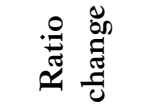 } & ?ֶ. & $\stackrel{+}{n}$ & $\stackrel{\text { L }}{\stackrel{0}{0}}$ & ָิ & $\stackrel{m}{0}$ & م̂ & $\stackrel{?}{0}$ & $\stackrel{f}{0}$ & $\stackrel{0}{0}$ & 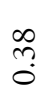 & $\stackrel{+}{+}$ \\
\hline \multirow{3}{*}{ 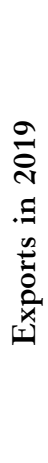 } & 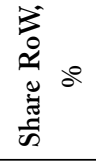 & $\overrightarrow{\overrightarrow{\mathrm{n}}}$ & $\vec{\imath}$ & $\begin{array}{l}\overleftarrow{6} \\
\underset{7}{\gamma}\end{array}$ & $\begin{array}{l}\vec{b} \\
\infty \\
\stackrel{0}{v}\end{array}$ & $\begin{array}{l}\vec{\infty} \\
\text { in } \\
\text { in }\end{array}$ & $\stackrel{\overleftarrow{m}}{m}$ & $\underset{\infty}{\vec{\infty}}$ & $\begin{array}{l}\vec{i} \\
\stackrel{N}{v}\end{array}$ & $\begin{array}{l}\overrightarrow{0} \\
\stackrel{0}{n}\end{array}$ & $\vec{\rightleftarrows}$ & $\begin{array}{l}\vec{\infty} \\
\dot{f}\end{array}$ \\
\hline & 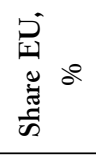 & $\overrightarrow{\hat{\sigma}}$ & $\begin{array}{l}\vec{\infty} \\
\overrightarrow{\vec{d}}\end{array}$ & $\begin{array}{l}\overleftarrow{T} \\
\infty \\
\stackrel{N}{v}\end{array}$ & 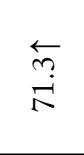 & $\overleftarrow{\curvearrowright}$ & $\overrightarrow{\hat{\sigma}}$ & $\underset{\infty}{\overleftarrow{\infty}}$ & 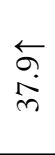 & $\vec{b}$ & 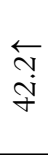 & $\begin{array}{l}\overleftarrow{n} \\
0 \\
0\end{array}$ \\
\hline & 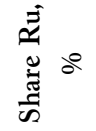 & $\underset{\sim}{\stackrel{\longrightarrow}{r}}$ & $\begin{array}{l}\vec{n} \\
\stackrel{\sim}{\sim}\end{array}$ & $\begin{array}{l}\vec{n} \\
\tilde{D} \\
\tilde{n}\end{array}$ & $\begin{array}{l}\overrightarrow{0} \\
0 \\
0\end{array}$ & $\begin{array}{l}\vec{\sim} \\
\stackrel{i n}{n}\end{array}$ & $\begin{array}{l}\overrightarrow{0} \\
0\end{array}$ & $\vec{m}$ & $\begin{array}{l}\vec{b} \\
\stackrel{i}{v}\end{array}$ & $\vec{\Omega}$ & 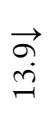 & $\overrightarrow{\stackrel{\sim}{\sigma}}$ \\
\hline \multirow{3}{*}{ 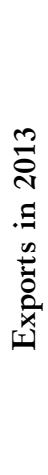 } & 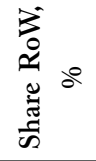 & $\begin{array}{l}\mathfrak{N} \\
\stackrel{f}{*}\end{array}$ & $\stackrel{1}{\dddot{0}}$ & $\vec{r}$ & $\stackrel{\vec{c}}{\stackrel{\infty}{m}}$ & 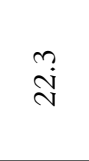 & $\stackrel{n}{\sim}$ & $\stackrel{9}{\beth}$ & $\stackrel{+}{\dot{m}}$ & $\begin{array}{l}\text { Ln } \\
\qquad 0 \\
\text { in }\end{array}$ & $\begin{array}{l}\infty \\
\dot{+} \\
\text { in }\end{array}$ & $\dot{m}$ \\
\hline & 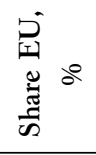 & $\dot{r}$ & $\begin{array}{l}\stackrel{n}{\sim} \\
\stackrel{1}{-}\end{array}$ & ت & $\begin{array}{l}n \\
\\
\end{array}$ & $\ddot{0}$ & $\begin{array}{l}\stackrel{n}{2} \\
\stackrel{2}{ }\end{array}$ & $\hat{6}$ & $\stackrel{\vec{i}}{\vec{v}}$ & $\begin{array}{l}\stackrel{+}{\oplus} \\
\stackrel{\infty}{\sim}\end{array}$ & $\stackrel{\mathfrak{y}}{\tilde{C}}$ & $\stackrel{\leftrightarrow}{\stackrel{\theta}{\prime}}$ \\
\hline & 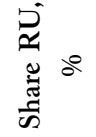 & $\begin{array}{l}\stackrel{N}{~} \\
\stackrel{n}{2}\end{array}$ & 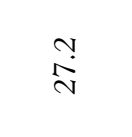 & $\mid \begin{array}{l}1 \\
1 \\
0 \\
0\end{array}$ & $\stackrel{+}{\infty}$ & $\stackrel{\text { m}}{\kappa}$ & $\underset{\sim}{\sim}$ & $\vec{v}$ & $\hat{\theta}$ & 곰 & $\begin{array}{l}\dot{0} \\
\dot{\sim}\end{array}$ & 官 \\
\hline & 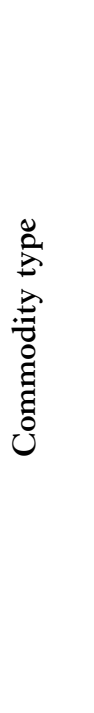 & 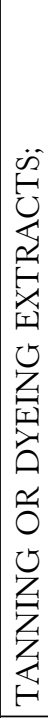 & 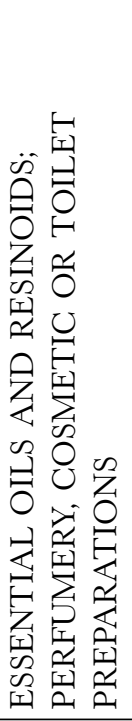 & 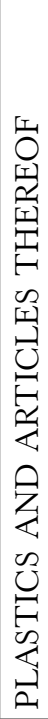 & 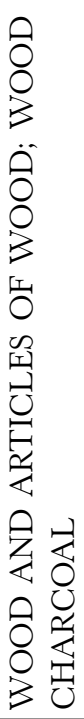 & 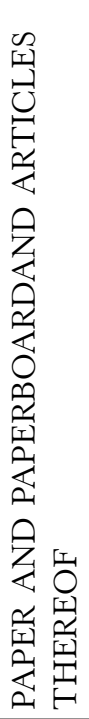 & 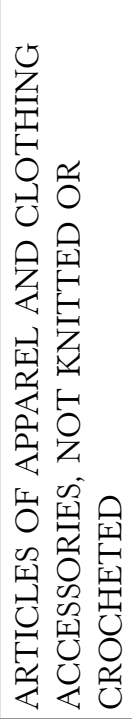 & 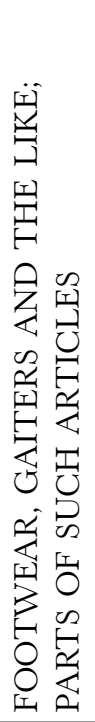 & 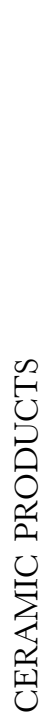 & 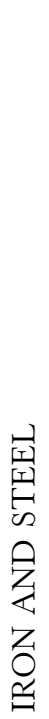 & 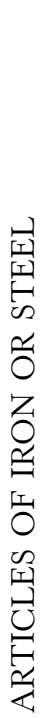 & 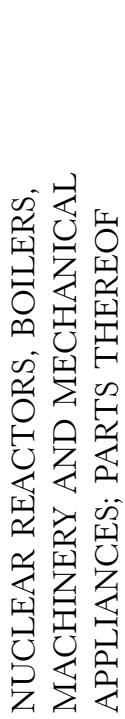 \\
\hline & & लै & $m$ & ले & J & $\stackrel{\infty}{+}$ & $\widetilde{\sigma}$ & $\vec{b}$ & 8) & $\mathfrak{N}$ & $\cong$ & $+\infty$ \\
\hline
\end{tabular}


Ukraine's foreign trade: measuring dichotomies between East and West

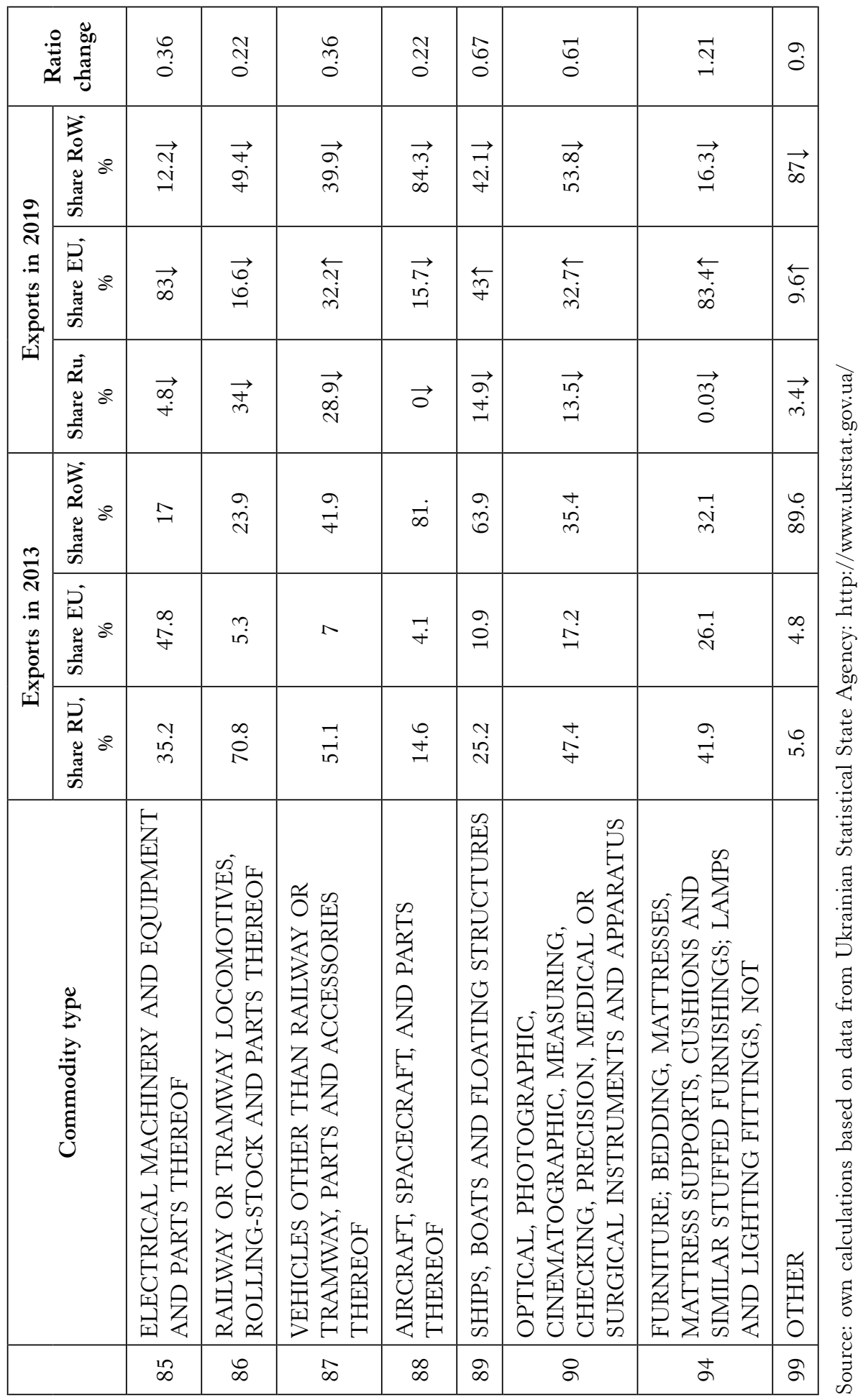


In what concerns the Ukrainian exports to the EU, the nominal value of exports increased by 31\%, that is from 14.2 billion dollars in 2013 to 20.7 billion in 2019 - the highest value of exports ever to the EU, the fact that can be attributed to the effects of the Free Trade Area between the Country and the Union.

Observing Table 1 we can find second dichotomy between Ukraine's East biggest partner Russia and the EU, namely in different commodity structure of exports. According to Eurostat classification on high, medium and low technology-intensive products, ${ }^{14}$ Ukrainian exports to Russia before 2014 displayed more 'advanced' structure. For example, in commodity groups: "Electrical Machinery"; "Articles of Iron and Steel”; "Ships, Boats and Floating Structures"; "Aircraft, Spacecraft and Parts thereof" exports to Russia in 2013 were averagely three times higher than to the EU. European market is rather segmented for Ukrainian exports since machine-building sector before 2014 was orientated mainly toward CIS countries with the Russian market receiving a predominant part in it, whereas major part of exports to the EU constituted agriculture, food products and raw materials (see Table 1 ).

In 2019 exports to the EU have increased (up arrows in Table 1) in almost all commodity groups in comparison to 2013. The share of the EU in technologically intensive commodity groups like machinery, transport, floating structures (positions 84 to 90) has increased as well, but due to overall sharp decrease in these industries to say that the EU market was able to compensate for the loss of Russian market so far is not possible. The growth between Ukraine and the EU in the period between 2013 and 2019 years relates mainly agricultural and food products (positions 2-22 in Table 1).

A positive tendency can be observed here, is the quality of exports to the EU increased. According to the Berlin Economics GmbH study, the share of processed products in Ukrainian exports to the EU increased by $10 \%$ to $43 \%$ between 2013 and 2019 and the share of raw materials dropped by $5 \% 15$. Ukrainian businesses during the first years of market liberalizations have withstood the high competition on the EU markets and showed an ability to further expand not only quantitatively but also qualitatively their products into the EU markets. Alignment with high

14 Eurostat Classification on high/medium/low technology products, Retrieved from https:// ec.europa.eu/eurostat/cache/metadata/Annexes/htec_esms_an3.pdf (16.08.2020).

$15 \mathrm{BE}$ Berlin Economics GmbH: https://berlin-economics.com/wp-content/uploads/ The-economic-effect-of-the-DCFTA-on-Ukraine-Moldova-and-Georgia-\%E2\%80\%93A-comparative-analysis.pdf (17.08.2020). 
EU standards will help Ukrainian producers to expand their exports into another world's markets easier ${ }^{16}$. A good example of this are the "Plastics and Articles thereof", in this important commodity group Ukrainian exporters within last six years were able to increase tangibly exports not only to the EU but to other countries in the world, which is partially an effect of increased quality of the products.

Apart of agriculture and food industries the growth in exports to the EU occurred as well in consumer and household goods. In this regard separately needs to be distinguished the success in the exports of furniture (position 94), cloth (positions 62, 64) and wood and articles of wood (position 44). Exports of these technologically relatively intensive products increased and their exports to the EU constitute from 75\% to $97 \%$ of all exports in 2019. In counterweight to lost Russian marked Ukrainian producers were able to partially compensate a loss in important industries like nuclear reactors, boilers, machinery and mechanical appliances, articles of iron and steel, plastics and articles thereof by exporting more into the EU markets ${ }^{17}$.

Concluding previous paragraphs is possible to retrace the second dichotomy which lies in different commodity structures of Ukrainian exports to the biggest eastern trade partner Russia Federation and to the EU. Ukrainian exporters within last decade suffered a significant loss in key industries - articles of iron and steel, machinery, transport, aviation. Significant part of this loss falls to Russian market. Ukrainian exporters gained in the EU markets first of all quantitatively having reached the highest volumes of the exports in 2019 and as well qualitatively having increased the quality of exporting production.

\section{Conclusions}

The main problem in Ukraine's foreign trade activity is a worrying tendency of the constantly lowering quality of exports. Basically, what has happened during passed decade is that Ukraine gradually moved from the status of an exporter of metallurgical, machinery and chemical products to the status of an exporter of agricultural, mineral raw

16 N. Andryeyeva, D. Zinkovska, Implementing the EU norms and standards in the agricultural industry of Ukraine and the increase of its international competitiveness, Kiev 2016, p. 96.

17 EUROSTAT: https://ec.europa.eu/trade/policy/countries-and-regions/countries/ ukraine $/ \#: \sim$ : text $=$ Trade $\% 20$ picture\&text $=$ Ukraine\%20exports $\% 20$ to $\% 20$ the $\% 20$ EU,\%E2\%82\%AC24.2\%20bn\%20in\%202019 (14.08.2020) 
materials and metallurgical semi-finished products. Undoubtedly, such a change can't contribute to the country's modernization potential and doesn't favor the country's economic performance. If in following decade this tendency will stay further stable the situation in foreign trade will become catastrophic.

Starting from 2016 the value of trade with the EU has been constantly growing from year to year and the potential of the DCFTA is further can be discovered. An important achievement is that the share of processed products in exports to the world's most competitive EU market has increased and the share of raw materials diminished. That means an increased competitiveness of Ukrainian products elsewhere in the world with the potential to find new markets.

In 2014 Ukraine did a logical choice that complied with its multivector foreign policy. The presupposition that the free trade between Ukraine and Russia will survive an enactment of the DCFTA, has failed. Russia imposed trade restrictions just as it warned it would do. Essentially, almost only the thing that has happened in Ukraine's trade with the CIS countries is the loss of Russian market for Ukrainian high-tech producers. On the western direction Ukraine has gained in trade with the EU first of all quantitatively, exporting there mainly primary commodities and relying on benefits which high competition on EU markets can bring in long-run to Ukrainian producers.

Basing on findings, the following recommendations can be defined:

- Consider elaborating a state-led multiapproach system using subsidies, direct payments, low-cost loans, tax exemption and, till the possible extent in the context of DCFTA, the protective measures to address the trend of constantly lowering quality of exports.

- To maintain and try to boost further the exports increasing tendency of last four years with the EU using modernization potential that high competition on EU markets already brought and further will bring to the Ukrainian producers. Alignment to the EU standards has already increased Ukrainian exports in food industry and in metallurgy (articles of iron and steel) to the EU and to third countries making Ukrainian goods more competitive throughout the world.

- From an economic point of view, it is reasonable to restore at least partially the trade relations with Russia, especially in the specific industries that can't be reoriented elsewhere due to the specificity of their production. First of all, it concerns space industry, aviation and railway transport. 


\section{References}

Andryeyeva N., Zinkovska D., Implementing the EU norms and standards in the agricultural industry of Ukraine and the increase of its international competitivenesss (Андрієєва Н., Зіньковська Д. Впровадження норм та стандартів ЄС у сільськогосподарській галузі України та підвищення міжнародної конкурентоспроможності, Київ 2016, Лублянки), Kiev 2016.

Dalyk V.P., Duliaba N.I., Ukraine's foreign trade: realities and prospects of development, »Scientific journal of Uzhhorodsky national university. Seriia: International economic relations and development» (Далик В. П., Дуляба Н.І., Зовнішня торгівля Украӥни: реалії та перспективи розвитку, Науковий вісник Ужгородського національного університету) 2016, No. 7 (1).

Luginiets S., Transformation of Ukrainian foreign trade flows in the context of Ukraine-EU association, «Journal of the European Economy» (Трансформація Української зовнішньої торгівлі в контексті Асоиіації з СС, «Журнал Свропейської економіки») 2017, No. 16 (3).

Mazaraki A.A., Foreign Trade of Ukraine: XXI Century: Monograph (Мазаракі А.А., Зовнішня торгівля України: XXI вік), Kуіv 2016. 